\title{
On the Lexical Background of the Amarna Glosses
}

\begin{abstract}
The gloss phenomenon is one aspect of the Amarna letters that has attracted much interest from scholars. Most studies on these glosses have focused on linguistic features, comparatively few studies have attempted to understand their cultural background. Based on the identification of some glosses which appear to be unnecessary from a functional point of view, we would like to propose, as a hypothesis, the possibility that these types of glosses could be elements scribes extracted from lexical lists they had used in their training with the purpose of hinting at their professional background.
\end{abstract}

Keywords: Amarna letters, glosses, lexical texts.

1. Ever since the pioneering work of Zimmern (1891), the gloss phenomenon is one aspect of the Amarna letters that has attracted much interest from scholars. ${ }^{1}$ Izre'el (2003: 15) defines Amarna glosses as 'words that are inserted within the sequence of the text either to clarify or to replace an Akkadian word or a Sumerian logogram which might be wrongly interpreted when read in Egypt. The glosses are usually indigenous lexemes, mostly West Semitic, but also Hurrian or other local languages, of unidentified origin. Glosses can sometimes be Egyptian, and Akkadian glosses (usually used for interpreting a Sumerogram) are not rare. One can even find glosses in Sumerian, serving as a reading aid for a logogram. ... Glosses were usually marked as such by a special cuneiform sign ... which is called a Glossenkeil (“a gloss-wedge”).' Most studies on these glosses have focused on linguistic features, ${ }^{2}$ primarily because Canaanite glosses are viewed as linguistic evidence for Proto-Hebrew. ${ }^{3}$ Comparatively few studies have attempted to understand their cultural background, their raison d'être. ${ }^{4}$ In the last few

\footnotetext{
${ }^{1}$ This article is one result of the research project 'Native Languages, linguae francae, and Graphics Traditions in Late Bronze Age Syria and Palestine: Three Case Studies (Canaan, Ugarit, Emar)' (FFI2011-25065), funded by the Spanish Ministry for Economic Affairs and Competitiveness within the National Plan for Scientific Research, Development and Technological Innovation (I+D+I). I would like to thank Dr. Camille Lecompte (CNRS, Paris) for having taken the time to discuss with me some aspects of this paper and for his valuable comments. Abbreviations follows those found in the Reallexikon der Assyriologie 12 7/8; notice in addition: DS-NELL = Dutch Studies - Society of Near Eastern Languages and Literatures, $\mathrm{SEL}=$ Studi Epigrafici e Linguistici, TA $=$ Tel Aviv.

${ }^{2}$ See especially Sivan (1984) and Rainey (1996a-c).

${ }^{3}$ Cf., e.g., Izre'el (1995: 103); Steiner (1997: 146-147); Moran (2003: 343); L. Edzard (2011: 481).

${ }^{4}$ As pointed out especially by Izre'el (1995: 103; 2003: 16). See also von Dassow (2004: 652-653).
} 
years, however, authors such as Gianto (1995), Izre'el (1995), van der Toorn (2000), von Dassow (2004) and Siddall (2005) have put forward some hypotheses to try to explain why Amarna glosses were used. It remains the case, however, as Izre'el (1995: 103) pointed out, that 'no comprehensive evaluation of the gloss phenomenon has been undertaken'.

The following lines are also an attempt to contribute to the investigation of the use and cultural background of the Amarna glosses. Based on the identification of some glosses which appear to be unnecessary from a functional point of view, we would like to propose, as a hypothesis, the possibility that these types of glosses could be elements scribes extracted from lexical lists they had used in their training with the purpose of hinting at their professional background.

2. A study of the glosses for 'dust' provides a good introduction to the issue. Both Akkadian eperu and Canaanite 'aparu, 'dust' (< Proto-Semitic * 'apar-; cf. Kogan 2011: 189), are used as glosses in six letters from four different localities: Beirut (EA 136:3, 141:4, 143:11), Mušihuna (EA 195:5), ${ }^{5}$ Yurza (EA 316:4) and Aštartu (EA 364:8). The fact that they occur in the opening passages of the letters ${ }^{6}$ adds to their interest and highlights the question regarding what their function might have been. ${ }^{7}$

Letters EA 141-143 were sent by Ammunira, the ruler of Beirut. The palaeographic unity of the three letters was already pointed out by Knudtzon (1907-1915: 1236). ${ }^{8}$ They share an identical format and script and were written by a single scribe. ${ }^{9}$ EA 136 , sent by Rib-Haddi, king of Byblos, was written by this same scribe. ${ }^{10}$ The use made by

\footnotetext{
${ }^{5}$ Izre'el (2003: 28), for instance, assumes that EA 195 would have come from Kumidi. However, as I intend to show in a forthcoming study, this letter likely would have come from Mušihuna.

${ }^{6}$ Cf. also Mynářová (2007: 167).

${ }^{7}$ See, in a similar sense, von Dassow (2004: 655 n. 32).

${ }^{8}$ In a comment on letter EA 136, regarding which, see below n. 10.

${ }^{9}$ EA 141 and 142 (which I was able to collate) are housed at the British Museum. One fragment of EA 143 (collated) is kept at the Vorderasiatisches Museum, another fragment (not collated) of the same letter is at the Egyptian Museum in Cairo. Regarding the petrographic analyses of the three tablets EA 141-143 see Goren / Finkelstein / Na'aman (2004: 162-163).

${ }^{10}$ By the end of his rule as the king of Byblos, Rib-Haddi was exiled in Beirut, from where he sent letters EA 136-138 to the pharaoh. Knudtzon (1907-1915: 56 n. 2 and 1236) rightly pointed out that EA 136 shows an identical script and clay as the letters of Ammunira. Moran (1992: 217 n. 6) notes certain material and linguistic traits that differentiate EA 136 from the letters from Byblos, and van der Toorn
} 
this scribe both of logogram SAHAR.RA ${ }^{11}$ and of the gloss "dust" is summarised in the following table: ${ }^{12}$

\begin{tabular}{|l|l|l|l|l|}
\hline \multicolumn{1}{|c|}{ EA Letter } & \multicolumn{1}{c|}{ Logogram } & \multicolumn{1}{c|}{ Case } & \multicolumn{1}{c|}{ Gloss } & \multicolumn{1}{c|}{ Case } \\
\hline $141: 4^{13}$ & SAHAR.RA & genitive & $a-p a-r u$ & nominative $^{14}$ \\
\hline $143: 4^{15}$ & SAHAR.RA & genitive & - & - \\
\hline $143: 11^{16}$ & SAHAR.RA & genitive & ha-pa-ru & nominative $^{17}$ \\
\hline
\end{tabular}

(2000: 103) likewise concludes that this letter must have been the work of the scribe from Beirut. The petrographic analysis of the tablet assures that it comes from Beirut (Goren / Finkelstein / Na'aman 2004: 157 and 158). EA 136, therefore, cannot be considered part of the linguistic corpus from Byblos, as Gianto (1990: 2) does.

${ }^{11}$ The scribe of Beirut is the only one in the Amarna corpus who uses the variant SAHAR.RA (on this script see also below n. 47). The correct interpretation of SAHAR.RA was pointed out by Moran (1992: 228): 'Read SAHAR.RA [in EA 141:4], a frozen context form ('in the dust'), rather than SAHAR-ra (epera), an erroneous accusative'. Cf. also CAD A/2: 166. Other scholars (cf. for instance Gianto 1995: 68; Rainey 1996c: 179) believe it must be read SAHAR-ra, in which case SAHAR always seems to appear in the wrong case. It should be noted, however, that both EA 136:3 (SAHAR glossed by eperi, correctly in the genitive) and EA 142:3 (eperi, also properly in the genitive, without SAHAR) could suggest that the scribe indeed understood SAHAR.RA as a noun in the correct genitive case. In EA 141:12, 17 and 20, the scribe uses eperu in the correct genitive (written i-pi-ri).

${ }^{12}$ The table does not include EA 142:3 ([ù e-pé-r]i ša $2 \mathrm{Gİ}^{\mathrm{MEŠ}}-k a$, if we accept the reconstruction by Knudtzon 1907-1915: 596), because the scribe does not seem to have used the term SAHAR in this line and eperi, consequently, appears not to be a gloss.

${ }^{13}$ um-ma Am-mu-ni-ra / LÚ URU PÚ.HูÁ İR-ka u SAHAR.RA : a-pa-ru / ša GİR ${ }^{\mathrm{MEŠ}}-k a$ (EA 141:3-5).

${ }^{14}$ In EA 141:4 and 143:11, the two Canaanite forms (h)aparu, in the nominative, would seem to be incorrect, in contrast to the correct use of Akkadian eperi in EA 136:3 (gloss) and 142:3 (no gloss). However, the use of the nominative as a neutral base case in enumerations, a usage also attested at Ugarit (see Tropper 2000: 308; Huehnergard 2008, Polyglot S ${ }^{\mathrm{a}}$ Vocabulary: cf. Akkadian and Ugaritic columns), is correct, and the same pattern is used by this scribe in various other passages. In EA 136:18, e.g., LÚ.MEŠ.UN : ma-șa-ar-ta, 'garrison' (Rainey 1996a: 36; regarding a possible alternative reading and interpretation of this logogram see also Moran 1992: 217 n. 3, and Gianto 1995: 71), the Akkadian gloss is used in the correct accusative case, while in EA 141:44, BÀD-ši : huu-mi-tu, 'its wall', BÀD-ši is in the accusative case with a feminine singular suffix pronoun in the genitive (Rainey 1996a: 79): these elements (case and suffix pronoun) have no equivalent in the Canaanite gloss hōmitu, which (like (h)aparu) is in the nominative.

${ }^{15}$ [ù] SAHAR.RA ša 2 G[İR $\left.{ }^{\text {MEŠ }}-k a\right]$.

${ }^{16} i \check{s}$-pur LUGA]L EN-ia / a-na ÌR-šu ù a-na SAHAR.RA : ha-pa-ru / ša Gìn ${ }^{\mathrm{MEŠS}}$-šu.

${ }^{17}$ See above n. 14. 


\begin{tabular}{|l|l|l|l|l|}
\hline $136: 3^{18}$ & SAHAR & genitive & $e$-pé-ri & genitive \\
\hline
\end{tabular}

As noted above, the gloss for 'dust' is also used in letters from Mušihuna, Yurza and Aštartu. In EA 195:5 (Mušihuna), SAHAR ${ }^{\text {MEŠ }}$ : ep-ri, the scribe opts for the Akkadian variant epri. ${ }^{19}$ The scribe from Yurza also opts for the same variant, [SAHAR $\left.{ }^{?}\right]:{ }^{20} e p-[r] i$ (EA 316:4). The scribe from Aštartu, however, uses the Canaanite form 'aparu, i.e., SAHAR : a-pa-ru (EA 364:8). In this case, the nominative aparu could be required by the syntax of the sentence, ${ }^{21}$ though it seems more likely that it would have functioned like the glosses (h)aparu and hōmitu from Beirut. ${ }^{22}$ The following table summarizes these data:

\begin{tabular}{|l|l|l|l|}
\hline \multicolumn{1}{|c|}{ EA Letter } & \multicolumn{1}{c|}{ Logogram } & \multicolumn{1}{c|}{ Gloss } & \multicolumn{1}{c|}{ Case } \\
\hline EA 195:5 & SAHAR $^{\text {MES }}$ & $e p-r i$ & genitive \\
\hline EA 316:4 & [SAHAR $\left.^{?}\right]$ & $e p-[r] i$ & genitive \\
\hline EA 364:8 & SAHAR & $a-p a-r u$ & nominative \\
\hline
\end{tabular}

3. Concerning the practical purpose of these Akkadian and Canaanite glosses of SAHAR, in principle it could be assumed that ep(e)ri and (h)aparu provide some nuance or clarification of the primary meaning of the logogram preceding them. This possibility, however, should be ruled out based on the following facts: (a) in the aforementioned cases, SAHAR and its glosses appear in the opening passages of the letters, that is, in set expressions found within a standardized context allowing little room for ambiguity; (b) the scribe from Beirut skips the gloss in EA 143:4, and hence,

\footnotetext{
${ }^{18} u m$-ma $r i-i b$ - ${ }^{\mathrm{d}} \mathrm{IS} H \mathrm{HUR}$ ÌR-ka / SAHAR : e-pé-ri ša $2 \mathrm{GİR}^{\mathrm{MEŠ}}-k a$. In this case, SAHAR does not have the element .RA, and the genitive case is correctly used in Akkadian eperi, which is thus probably an 'equivalent gloss' (cf. Gianto 1995: 68). Alternatively, it could be a 'pronunciation gloss' like that used by the scribe in line 28 of the same letter: DÙG.GA : $t u-k a$ 'alliance of friendship (EA 136:28); see in this respect Moran (1992: 217 n. 5).

${ }^{19}$ A variation of Akkadian eperu, cf. also CAD E, 184, 195. The gloss should be understood as the (correct) plural oblique case (eprī), cf. Rainey (1996a: 143).

${ }^{20}$ Cf. Knudtzon (1907-1915: 919 n. f): 'Kurz vor ip (vorn unten verstümmelt) scheint oben in der Zeile die obere Spitze eines schrägen Keils vorhanden zu sein'.

${ }^{21} a-n a-k u$ İR / LUGAL EN-ia / SAHAR : a-pa-ru ša / 2 GİR $^{\mathrm{MEŠs}}-\check{u} u$, 'I am the servant of the king, my lord, the dirt at his feet' (EA 364:6-9).

${ }^{22}$ See above n. 14.
} 
apparently did not think it necessary for a better understanding of SAHAR and of the formula employed; (c) over 60 Amarna letters from diverse localities use the term 'dust' written only syllabically in their introductions, ${ }^{23}$ while eight other letters (besides EA 143:4) use only SAHAR (EA $226: 4 ; 229: 5 ; 366: 5 ; 233: 7 ; 234: 5 ; 235: 6 ; 241: 5 ; 255: 4$ ).

Potentially relevant is also the fact that scribes from geographically distant localities share a common way of writing the glosses. The scribes from Beirut (EA 141) and Aštartu (EA 364) opt for the writing a-pa-ru, while the scribes from Mušihuna ${ }^{24}$ (EA 195) and Yurza (EA 316) use ep-ri. Are these equivalences in the writing of the glosses mere coincidence?

4. One can also compare the use of the gloss išātu, 'fire', employed by different scribes from various localities.

\begin{tabular}{|c|c|c|c|}
\hline EA / RS Letter & Logogram & Gloss & Provenance \\
\hline EA $185: 19.32$ & IZI & $i-s ̌ a-t i$ & Hazi \\
\hline EA $189: 12^{25}$ & ${ }^{\mathrm{d}} \mathrm{IZI}^{\mathrm{MES}}$ & $e-s ̌ a-t e$ & Qadeš \\
\hline RS 16.111:12 & IZI & $i-\check{s} a-t i$ & Amurru \\
\hline EA 306:32 & $\mathrm{IZI}]^{\mathrm{MES}}$ & $i-s ̌ a-t i$ & Ashkelon / Gaza \\
\hline
\end{tabular}

The scribe of letter EA 185 thought it necessary to gloss the logogram IZI, 'fire', using Akkadian išātu in lines 19 and 32, i.e., (wašāru) i-na IZI : i-ša-ti. In lines 24, 39 and 60 of the same letter, however, he uses išātu again in similar context, but without a gloss function. ${ }^{27}$ EA 185 and EA 189 would seem to suggest a northern origin of the gloss, an impression supported by the presence of the same gloss in the letter from Amurru, RS 16.111, where one finds (̌̌akānu) $i$-na ŠÀ IZI : $i-\check{s} a-t i{ }^{28}$ However, much

\footnotetext{
${ }^{23}$ References in Ebeling (1915): 1377 (aparu), 1404 (epiru), 1539 (upru); Rainey (1978): 64 (aparu), 70 (eperu), 98 (upru). EA 244:33 uses up-ri in the body of the message.

${ }^{24}$ Regarding the location of Mušihuna in the Beqa' see Vita (2005).

${ }^{25}$ This example and $i$-ša-ti in EA 306:32 (see below) are not preceded by a gloss mark. Rainey (1996a: 36) presents more examples of this kind.

${ }^{26} \mathrm{RS}=$ Ras Shamra.

${ }^{27}$ The scribe does not use any more glosses in this letter.

${ }^{28}$ Izre'el (1991a: 31, 115); (1991b: 66).
} 
farther to the south the scribe of the letters of Šbandu ${ }^{29}$ (EA 301-306), ${ }^{30}$ sent from Ashkelon or Gaza, ${ }^{31}$ also uses it in EA 306:32, i.e., (̌̌arāpu) $\left[i-n a\right.$ IZII ${ }^{\mathrm{MEŠ}} i$-ša-ti. As in the case of SAHAR, however, it does not seem that it was actually necessary to explain or

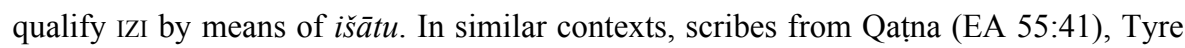
(EA 151:56), Hašabu (EA 174:17) and Enišasi (EA 363:14) use exclusively išătu, ${ }^{32}$ whereas scribes (again) from Qațna (EA 53:39) and Hazi (EA 186:16.31), but also from Byblos (EA 126:52), only use IZI. In this sense, the usage of the scribe of EA 53 and 55 from Qaṭna is significant, ${ }^{33}$ as in the former he uses only IZI, in the second only išătu. ${ }^{34}$

5. The glosses ep(e)ri/(h)aparu and išātu show that Amarna scribes could use glosses that were unnecessary from a functional point of view, as they were not needed for a better understanding of the glossed term, of the immediate context thereof or of the overall message of the letter. Moreover, other cases can be added, such as the use of the noun $p \hat{u}$, 'mouth', ${ }^{35}$ as a gloss in letters from Amurru, ${ }^{36}$ Byblos, ${ }^{37}$ Beirut $^{38}$ Sidon $^{39}$ and Mušihuna. ${ }^{40}$ The use of ${ }^{\text {(UZU) }}{ }^{\mathrm{KA}}$ without a gloss actually posed no problems, as shown

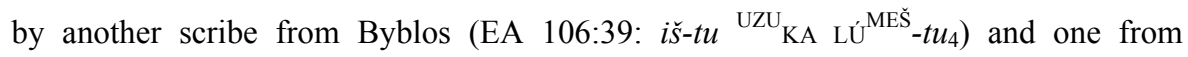

\footnotetext{
${ }^{29}$ The king of a locality not mentioned in his correspondence.

${ }^{30}$ Letters EA 301-306 were written by the same scribe, as shown by Moran's (1992: 347 n. 1) comment regarding EA 313.

${ }^{31}$ Goren / Finkelstein / Na'aman (2004: 297).

${ }^{32}$ Cf. also EA 176:13 (very fragmentary context), a letter from a king whose name is not preserved and whose locale is unspecified.

${ }^{33}$ EA 53 and 55 are indeed the product of the same scribe, as I was able to confirm in my collation of both tablets at the British Museum.

${ }^{34}$ The scribe of EA 62 from Amurru also uses only IZI-te $e^{\mathrm{MEŠ}}$ (1. 19; Izre'el 1991a: 115).

${ }^{35}$ It is impossible to determine whether $p \hat{u}$ as a gloss is an Akkadian or a Northwest Semitic term; cf. also Izre'el (2003: 28).

${ }^{36}$ EA 160:12, 17: ${ }^{\mathrm{UZU}} \mathrm{KA}$ pi- $i$. In line 17 if one assumes the reconstruction $i \check{s}-t u{ }^{\mathrm{UZU}} \mathrm{K}[\mathrm{A} p i-i]$.

${ }^{37}$ EA 79:12: ${ }^{\mathrm{UZU}} \mathrm{KA}: p i-i$. The scribe uses $p \hat{u}$ again in identical contexts but without the gloss function: $a-$ $n a p^{\prime}-i{ }^{\mathrm{I}} \mathrm{I} \mathrm{R}-a-\check{s} i-i r-t a(\mathrm{EA} 79: 22)$.

${ }^{38}$ EA 137:72: KA pí.

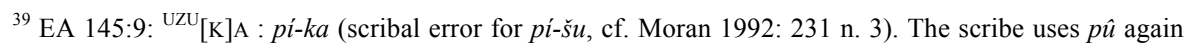
in identical contexts but without the gloss function: $\check{s} a-a-r i$ pí-i-šu (EA 145:20).

${ }^{40}$ EA 195:22-23: ${ }^{\mathrm{UZU}} \mathrm{KA}: p i ́-i$.
} 
Jerusalem (EA 290:26, 27: a-na KA-i). ${ }^{41}$ Once more, this gloss seems to have been unnecessary for the correct understanding of the message.

A further instance could be seen in the use of the Canaanite term kilübu, 'cage, basket', as a gloss of Akkadian huharu, 'bird trap', in the context of the proverb 'like a bird which lies in a hu-ha-ri : ki-lu-bi trap : cage am I' ${ }^{42}$ All attestations are found in five letters from Rib-Hadda of Byblos (EA 74:46, 79:36, 81:35, 105:9, 116:18), written by at least four different scribes. ${ }^{43}$ One of these scribes, however, that of EA 79, also uses this proverb in two letters (EA 78:13-16; EA 90:39-42), employing huharu without the gloss, thus showing that the gloss kilūbu was functionally unnecessary in the context of that proverb. ${ }^{44}$

Other Amarna glosses equally attested to in two or more letters could be studied from this perspective.

6. What might have been the ultimate reason for scribes to use the glosses discussed above? For our part, we are not, at least for now, in a position to give a clear and unequivocal answer to this question. Speculative as it may seem, we would like nevertheless to put forward the following possibility. While the aforementioned glosses (and other glosses which might be in the same situation) do not seem to have been necessary from a functional point of view, that is, they do not meet the functions traditionally attributed to the Amarna glosses (cf. §1), perhaps their raison d'être rests on more symbolic ground. An explanation can be perhaps sought in the training of the scribes, in the sense that these glosses could somehow directly reflect elements from the lexicographical education of the scribes. ${ }^{45}$ The scribes who used the kind of glosses discussed above may have wished to hint in their letters at their training as writing professionals and their expertise as scribes. This would be a form of intertextuality

\footnotetext{
${ }^{41}$ For the reading, see Rainey (1978: 87), Moran (1992: 334 n. 4).

${ }^{42}$ The proverb shows some variation (cf. CAD H, 225), though gloss and the glossed term are identical in all five letters. Regarding this gloss see Sivan (1984: 237) and Gianto (1995: 69, 'individuating gloss').

${ }^{43}$ As will be shown in a forthcoming study.

${ }^{44}$ See Knudtzon's observations on huharu in EA 78:14 (1907-1915: 387 n. 1) and EA 90:40 (1907-1915: 427 n. c).

${ }^{45}$ The terms $e p(e) r i, i s ̌ a ̄ t u$ and $p \hat{u}$, for exemple, were all part of various Mesopotamian lexical lists, some also attested to in Canaan in the Bronze Age; cf. Tadmor (1977), Huehnergard / van Soldt (1999), Horowitz / Oshima / Sanders (2006: 42-43, 73-74).
} 
among letters and lexical lists similar to that already noticed in Mesopotamia, for instance, between lexical and literary texts. ${ }^{46}$ Some indications could possibly point in this direction, ${ }^{47}$ though this explanation leaves important questions unanswered ${ }^{48}$. We, however, believe that this could be a fruitful line of investigation, already begun, from a different perspective, half a century ago by Artzi (1963), though (as far as I know) it has not been adequately developed subsequently. ${ }^{49}$

If this hypothesis should prove correct, some of the Amarna glosses, such as those discussed in this paper, may be of assistance in the identification of underlying lexical texts and, consequently, to a more accurate reconstruction of the curriculum of Canaanite scribes. ${ }^{50}$

\footnotetext{
${ }^{46}$ See Veldhuis (1997: 125-128; 2004: 95-106). Concerning the composition Nanše and the Birds, Velduis (2004: 105) points out that ' $(t)$ he text seems to be designed in a way that connects to typical knowledge texts, to suggest that there is a claim to knowledge here' (my italics).

${ }^{47}$ Pairings such as SAHAR : (h)aparu or huhari : kilübi could also be a reflection of Mesopotamian lexical lists from the $14^{\text {th }}$ century, locally adapted and with the addition of a Canaanite column (similar to the way other lexical texts from the $13^{\text {th }}$ century found in Tell Aphek and in Ashkelon are produced; see Rainey (1975: 125-128), (1976: 137-139); Horowitz / Oshima / Sanders (2006: 29-32, 42-43); Huehnergard / van Soldt (1999). The writing SAHAR.RA (cf. n. 11) could reflect a Sumerian genitive (attested, e.g., in Hh VII B 27: GIŠMAR.SAHAR.RA = mar e-pi-ri, MSL VI, 117; CAD E, 185); this would not necessarily indicate knowledge of Sumerian on the part of the scribe, at least not extensive knowledge, but might rather be understood as an oblique scribal reference to lexical texts that had formed part of his training, where the Sumerian genitival form SAHAR.RA was related to eperu.

${ }^{48}$ For instance, what criteria could have been adopted by each scribe when extracting from the lexical lists certain terms (and not others) or certain equivalences (and not others) and placing them in letters as glosses.

${ }^{49}$ Based on a comparative study of glosses mainly in Akkadian texts from Ugarit, Artzi (1963: XVI) pointed out among other conclusions that, 'It must be stressed that the Canaanite translations ... are used in a way analogous to the Akkadian ones, also present in the EA Tablets. The background of these latter is known: it can be found in lexical texts. Therefore it seems clear that the method of employing the Canaanite language as "translation" is a local innovation influenced by the Akkadian lexicographical, scribal, and traditional approach. ... The author suggests that these translations are signs of such quasilexicographical activity and proposes to call them "forerunners" and "partial representatives" of lexical units.' Some echoes of Artzi's proposal can be found in bibliographical summaries, e.g., in that by D.O. Edzard: (1985: 259 n. 78).

${ }^{50}$ Regarding cuneiform instruction in Canaan see von Dassow (2004: 666-673) and Horowitz / Oshima / Sanders (2006: 15-19).
} 


\section{Juan-Pablo Vita}

Consejo Superior de Investigaciones Científicas (CSIC)

Centro de Ciencias Humanas y Sociales (CCHS)

Instituto de lenguas y Culturas del Mediterráneo y Oriente Próximo (ILC)

C/ Albasanz 26-28

E - 28037 Madrid - SPAIN

jp.vita@csic.es 


\section{Bibliography}

Artzi, P. (1963): The 'Glosses' in the El-Amarna Tablets. A Contribution to the Study of Cultural and Writing Traditions among the Scribes of Canaan before the Israelite Conquest, Bar-Ilan 1, XIV-XVII, 1-34. (In Hebrew)

Ebeling, E. (1915): Glossar, in: J.A. Knudtzon, Die El-Amarna-Tafeln, vol. 2, Leipzig 1907-1915 (Aalen 1964): 1358-1554.

Edzard, D.O. (1985): Amarna und die Archive seiner Korrespondenten zwischen Ugarit und Gaza, in A. Biran et al. (eds.), Biblical Archaeology Today: Proceedings of the International Congress on Biblical Archaeology, Jerusalem, April 1984, Jerusalem: $248-259$.

Edzard, L. (2011): Biblical Hebrew, in S. Weninger (ed.), The Semitic Languages. An International Handbook, Berlin: 480-514.

Gianto, A. (1990): Word Order Variation in the Akkadian of Byblos, Roma.

Gianto, A. (1995): Amarna Lexicography: The Glosses in the Byblos Letters, SEL 12, $65-73$.

Goren, Y. / I. Finkelstein / N. Na'aman (2004): Inscribed in Clay. Provenance Study of the Amarna Tablets and Other Ancient Near Eastern Texts, Tel Aviv.

Horowitz, W. / T. Oshima / S. Sanders (2006): Cuneiform in Canaan. Cuneiform Sources from the Land of Israel in Ancient Times, Jerusalem.

Huehnergard, J. (1996): A Byblos Letter, Probably from Kāmid el-Lōz, ZA 86, 97-113.

Huehnergard, J. (2008): Ugaritic Vocabulary in Syllabic Transcription, Atlanta.

Huehnergard, J. / W. van Soldt (1999): A Cuneiform Lexical Text from Ashkelon with a Canaanite Column, IEJ 49, 184-192.

Izre'el, Sh. (1991a): Amurru Akkadian: A Linguistic Study, Atlanta, vol. 1.

Izre'el, Sh. (1991b): Amurru Akkadian: A Linguistic Study, Atlanta, vol. 2.

Izre'el, Sh. (1995): The Amarna Glosses: Who Wrote What for Whom? Some Sociolinguistic Considerations, in Sh. Izre'el / R. Drory (eds.), Language and Culture in the Near East (IOS 15), Leiden, 101-122.

Izre'el, Sh. (2003): Vocalized Canaanite: Cuneiform-Written Canaanite Words in the Amarna Letters. Some Methodological Remarks, DS-NELL V, 13-34.

Knudtzon, J.A. (1907-1915): Die El-Amarna-Tafeln, Leipzig (Aalen 1964).

Kogan, L. (2011): Proto-Semitic Lexicon, in S. Weninger (ed.), The Semitic Languages. An International Handbook, Berlin-Boston: 179-258.

Moran, W.L. (1992): The Amarna Letters, Baltimore - London. 
Moran, W.L. (2003): Amarna Studies. Collected Writings. Edited by J. Huehnergard and Shlomo Izre'el, Winona Lake.

Mynářová, J. (2007): Language of Amarna - Language of Diplomacy. Perspectives on the Amarna Letters, Prague.

Rainey, A.F. (1975): Two Cuneiform Fragments from Tel Aphek, TA 2, 125-129.

Rainey, A.F. (1976): A Tri-Lingual Cuneiform Fragment from Tel Aphek, TA 3, 137140.

Rainey, A.F. (1978): El Amarna Tablets 359-379. Supplement to J.A. Knudtzon, Die El-Amarna Tafeln (AOAT 8), Neukirchen-Vluyn.

Rainey, A.F. (1996a): Canaanite in the Amarna Tablets, vol. 1, Leiden.

Rainey, A.F. (1996c): Canaanite in the Amarna Tablets, vol. 3, Leiden.

Siddall, L.R. (2005): Was There a Purpose for the Use of West-Semitic in the Amarna Letters from Syria-Palestine? BACE 16, 85-99.

Sivan, D. (1984): Grammatical Analysis and Glossary of the Northwest Semitic Vocables in Akkadian Texts of the $15^{\text {th }}-13^{\text {th }}$ c. B.C. from Canaan and Syria (AOAT 214), Neukirchen-Vluyn.

Steiner, R.C. (1997): Ancient Hebrew, in R. Hetzron (ed.), The Semitic Languages, London: 145-173.

Tadmor, H. (1977): A Lexicographical Text from Hazor, IEJ 27, 98-102.

Tropper, J. (2000): Ugaritische Grammatik (AOAT 273), Münster.

van der Toorn, K. (2000): Cuneiform Documents from Syria-Palestine. Texts, Scribes, and Schools, ZDPV 116, 97-113.

Veldhuis, N. (1997): Elementary Education at Nippur. The Lists of Trees and Wooden Objects, Ph.D. dissertation, University of Groningen.

Veldhuis, N. (2004): Religion, Literature, and Scholarship: The Sumerian Composition "Nanše and the Birds", Leiden-Boston.

Vita, J.-P. (2005): The Town of Mušihuna and the Cities of the 'Beqa' Alliance', SEL $22,1-7$.

von Dassow, E. (2004): Canaanite in Cuneiform, JAOS 124, 641-674.

Zimmern, H. (1891): Kanaanäische Glossen, ZA 6, 154-158. 